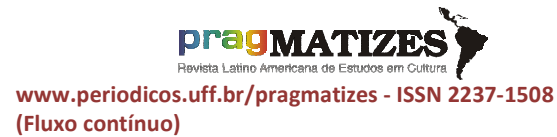
(Fluxo contínuo)

\title{
A crescente precariedade do trabalho na cultura na cidade do Rio de Janeiro
}

DOI: https://doi.org/10.22409/pragmatizes.v11i21.48928

Ana Lúcia Pardo ${ }^{1}$

"A nova cultura começa quando o trabalhador e o trabalho são tratados com respeito".

(Máximo Gorky)

Resumo: Em que condições sobrevivem as trabalhadoras e os trabalhadores da Cultura? Essa e demais questões buscamos analisar, a partir do objeto de pesquisa concentrado no mercado de trabalho no setor cultural brasileiro na atualidade. Para tanto, utilizamos o estudo de caso como metodologia, que resultou na elaboração desse artigo. Na intenção de identificar o cerne das tensões, impactos, principais desafios e em que medida as/os profissionais enfrentam a situação de precariedade no trabalho, como também, que possíveis caminhos são apontados para corrigir as fragilidades dessa classe trabalhadora informal. Nessa direção, realizamos uma série de entrevistas em profundidade, através de uma pesquisa qualitativa, com perguntas abertas, direcionadas para uma parcela de trabalhadoras e trabalhadores que atuam em diversos segmentos artístico-culturais na cidade do Rio de Janeiro. Com base nas respostas levantadas nas entrevistas, apresentamos essa análise, comentada e referenciada em estudos e pesquisadores da área.

Palavras-chaves: trabalho; artes; cultura; precariedade; empreendedorismo; direitos.

\section{La precariedad creciente del trabajo en cultura en la ciudad de Rio de Janeiro}

Resumen: En qué condiciones sobreviven los trabajadores culturales? Ésta y otras cuestiones que buscamos analizar, a partir del objeto de investigación concentrado en el mercado laboral en el sector cultural brasileño hoy. Para eso, utilizamos el estudio de caso como metodología, lo que resultó en la elaboración de este artículo.

\footnotetext{
${ }^{1}$ Ana Lúcia Ribeiro Pardo. Pós-doutoranda em Cultura e Territorialidades na Universidade Federal Fluminense (CAPES-UFF). Doutora em Políticas públicas e formação humana pela Universidade do Estado do Rio de Janeiro, UERJ, Brasil. E-mail: anapardo.teatralidade@gmail.com https://orcid.org/0000-0002-7671-438X
} 
Con el fin de identificar el núcleo de las tensiones, impactos, principales desafíos y la medida en que los profesionales enfrentan la situación de precariedad en el trabajo, así como qué posibles caminos se señalan para corregir las debilidades de esta clase trabajadora informal. En esta dirección, realizamos una serie de entrevistas en profundidad, a través de una investigación cualitativa, con preguntas abiertas, dirigidas a un grupo de trabajadores y trabajadoras que laboran en diversos segmentos artísticos y culturales en la ciudad de Río de Janeiro. A partir de las respuestas planteadas en las entrevistas, presentamos este análisis, comentado y referenciado en estudios e investigadores del área.

Palabras clave: trabajo; arte; cultura; precariedad; emprendimiento; políticas públicas.

\title{
The growing precariety of work in culture in Rio de Janeiro city
}

\begin{abstract}
In what conditions do cultural workers survive? This is the other survey that we seek to analyze, based on the object of investigation concentrated in the labor market in the Brazilian cultural sector today. For this, we used the case study as a methodology, which resulted in the elaboration of this article. In order to identify the core of the stresses, impacts, main challenges and the extent to which the professionals face the precarious situation in the work, as well as the possible ways to seign themselves to correct the weaknesses of this informal working class. In this direction, we carry out a series of in-depth interviews, through a qualitative investigation, with open questions, addressed to a group of workers and workers who work in various artistic and cultural segments in the city of Río de Janeiro. Based on the answers planted in the interviews, we present this analysis, commented on and referenced in studies and researchers in the area.
\end{abstract}

Keywords: work; arts; culture; precariousness; entrepreneurship; public policies.

\section{A crescente precariedade do trabalho na cultura na cidade do Rio de Janeiro}

A partir do objeto de pesquisa, concentrado na situação do mercado de trabalho no setor cultural brasileiro na atualidade, começamos por lançar as seguintes questões: sob que condições sobrevivem as trabalhadoras e os trabalhadores da
Cultura? Em que dimensão já passaram, e/ou ainda se encontram, em estado de precariedade e, em caso afirmativo, como é enfrentada tal situação? Como avaliam o mercado de trabalho na Cultura no Brasil e no mundo? Em que medida os problemas 


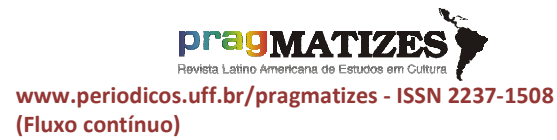
(Fluxo contínuo) vividos no mercado de trabalho da Cultura no Brasil são locais ou globais? Quais são as principais perdas, avanços e desafios para as trabalhadoras e os trabalhadores da Cultura? Que caminhos possíveis apontariam para melhorar as condições de trabalho na Cultura?

Para tanto, utilizamos o estudo de caso como metodologia, na intenção de identificar o cerne das tensões, desafios e avaliar em que medida as/os profissionais enfrentam a situação de precariedade no trabalho, como também, que possíveis caminhos são apontados para corrigir as fragilidades dessa classe trabalhadora informal. Nessa direção, realizamos uma série de entrevistas em profundidade, através de uma pesquisa qualitativa, com perguntas abertas, direcionadas para uma parcela de trabalhadoras e trabalhadores que atuam em diversos segmentos artístico-culturais (Artes Cênicas - Dança, Circo, Teatro, Arte Pública; Artes Visuais; Audiovisual; Produção Teatral; Publicidade, Comunicação Visual, Mídias Sociais), na cidade do Rio de Janeiro.

As perguntas desse questionário foram previamente enviadas às/os entrevistadas/os no início de janeiro de 2021, - por email e também através do WhatsApp, além de contatos telefônicos, a fim de evitar o contato presencial em função da pandemia, - resultando no retorno das respostas de 09 (nove) trabalhadoras/es da Cultura, sendo quatro mulheres e cinco homens, que nos foram concedidas de forma gradativa, no período compreendido entre o dia 05/01 ao dia 20/01/2021. Com base nas respostas levantadas nas entrevistas, apresentamos essa análise, comentada e referenciada em estudos e pesquisadores da área.

O presente estudo se utiliza basicamente de entrevistas, documentos e publicações que costumam ser usadas no estudo de caso. Com base nas respostas dos entrevistados, somadas às referências de estudos, dados, pesquisas e demais fontes e autores, além de palestras e seminários realizados na universidade, movimentos e fóruns artísticos, buscamos fazer uma análise acerca da situação atual do mercado de trabalho na Cultura. Segundo Robert Yin (2010, p. 39), o estudo de caso "é uma investigação empírica que investiga um fenômeno 


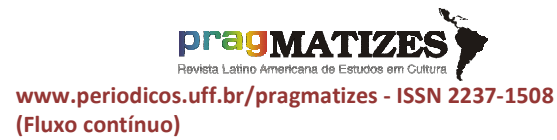
(Fluxo contínuo) contemporâneo em profundidade e em seu contexto de vida real, especialmente quando os limites entre o fenômeno e o contexto não são claramente definidos". Essa definição leva em consideração três condições básicas sobre estratégias de pesquisa: o tipo de questão de pesquisa, o controle do pesquisador sobre eventos comportamentais, e 0 foco no contemporâneo ao invés de fenômenos históricos. Ao delinear estas três condições, Yin argumenta que a escolha de estudo de caso seria a estratégia preferida quando "como" ou "por que" questões estão sendo colocadas; quando o investigador tem pouco controle sobre os eventos e; quando o foco está em um fenômeno contemporâneo dentro de algum contexto da vida real.

\section{Entrevistas com trabalhadores e} trabalhadoras da Cultura do Rio de Janeiro

Para esse estudo aqui apresentado, foram feitas, portanto, entrevistas em profundidade, com as/os seguintes artistas que trabalham em áreas e segmentos diversos: Célia Maracajá (Artes Cênicas e Audiovisual), Daphne Madeira (Artes
Cênicas - Dança), Denise Milfont (Artes Cênicas - Teatro), Erisvelton de Alencar Santana (Publicidade, Comunicação Visual e Redes Sociais), Gabriel Bezerra de Melo Júnior (Artes Cênicas - Circo), José Carlos Rosa Miranda (Produção Teatral), Wildson de Andrade França (Arte Pública Circense), Stanley Livingstone Whibbe (Microempresa de Elaboração e Produção de Projetos) e Ynaê Cortez de Morais (Artes Visuais, Audiovisual, Mídias Sociais). Nessa entrevista, a artista multimídia e pesquisadora Ynaê Cortez de Morais, 28 anos, afirma que após terminar a graduação em História da Arte não encontrou trabalho na área, tendo que migrar para o mercado de audiovisual, onde já tinha algum conhecimento, mesmo com uma baixa remuneração. "Enfrento muita dificuldade na remuneração de trabalhos autorais, por conta disso sou fotógrafa e editora freelancer de cinema, publicidade e mídias sociais". Ela aponta concentrações de recursos, burocracias e o uso mercadológico feito pelas empresas.

A meu ver o mercado de trabalho na cultura no Brasil é muito precarizado, os trabalhadores são predominantemente informais, há uma grande concentração de 


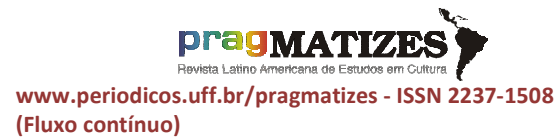
(Fluxo contínuo) renda em grandes produtoras. Vejo dois grandes problemas no mercado de cultura: a falta de recursos para o setor e a concentração dos recursos disponíveis. Embora muitos editais públicos e leis de incentivos estejam abertos a todos, os pequenos e médios produtores muitas vezes enfrentam grandes dificuldades em se inscrever, pois essas inscrições exigem documentações, licitações e burocracias que muitas vezes não estão ao alcance de um pequeno ou médio produtor. $\mathrm{O}$ incentivo indireto também apresenta diversas problemáticas, uma delas é que o incentivo via empresas muitas vezes é utilizado como um 'marketing social' das empresas que privilegiam grandes projetos e profissionais renomados. (MORAIS, 2021).

Ynaê considera que esses problemas são locais e provindos de uma falta de políticas públicas voltadas para a área que levem em conta a diversidade do país e a democratização do acesso a essas políticas. "Também acredito que os problemas são reflexos da inabilidade de muitos gestores sobre o próprio entendimento do que é cultura, como realizar políticas democráticas para área e difundir $o$ acesso da população". E considera o mapeamento e cadastramento de profissionais da cultura um grande avanço e os recursos provindos da Lei de Emergência Cultural Aldir Blanc, apresentada pela Comissão de Cultura da Câmara dos Deputados e implementada em 2020.

$\mathrm{Na}$ visão dessa artista, houve o entendimento, a valorização e o reconhecimento das culturas locais, assim como a iniciativa da desburocratização da inscrição dos profissionais e espaços relacionados aos pontos de cultura foi uma grande conquista. No entanto, aponta muitos problemas na execução dos recursos da lei por conta de diversas gestões municipais e estaduais. "Acredito que os maiores desafios sejam 0 investimento na área e a democratização dos recursos para que pequenos e médios produtores possam acessar esses recursos".

De fato, conforme ressalta Ynaê Cortez de Morais, o mercado de trabalho na cultura está atravessado pela precariedade. Sobretudo porque a grande maioria desses agentes, - com seus fazeres e saberes culturais, atua de forma autônoma, precária, informal, sem garantia alguma de direitos trabalhistas, previdenciários e tributários, dependendo, portanto, dos editais, que estão cada vez mais raros 


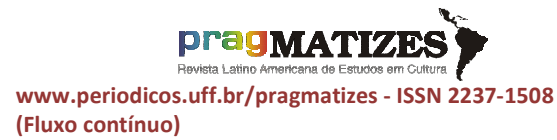
(Fluxo contínuo) nessas últimas gestões de governo, para manterem vivas as suas atividades. Além da dificuldade de acesso e apoio de uma grande parcela de trabalhadores da cultura, ocorrem distorções quanto ao uso dos recursos públicos, via incentivo indireto, por empresas e bancos, resultando nas recorrentes concentrações em grandes produtoras de eventos e de entretenimento.

A potência inventiva da cultura envolve uma força laborativa, um ofício, embora suas especificidades extrapolem o campo formal do chamado mundo do trabalho. Trata-se de uma classe trabalhadora que vive sob condições e relações extremamente precarizadas, sem qualquer garantia de renda, vínculos empregatícios registrados em carteira de trabalho, contrato ou documentação equivalente, sendo geralmente desprovida de benefícios como remuneração fixa, férias pagas, mecanismos de proteção social e de cobertura previdenciária. Esse quadro diferenciado de trabalho no setor cultural, - que compreende uma rica e extensa diversidade de atores, segmentos, expressões, linguagens, artes, culturas, que não são institucionalizadas, - muitas vezes não alcança a compreensão e o devido preparo técnico por parte dos gestores de órgãos públicos e privados para implementarem políticas que possam corrigir essas fragilidades e garantir os direitos trabalhistas, tributários previdenciários desses profissionais. Isso se revela também na dificuldade de contarmos com levantamentos consistentes e atualizados de cadastros, dados, desempenho e funcionamento dessas atividades. Esse ofício compreende não somente uma grande diversidade de perfis de trabalhadoras e trabalhadores da Cultura, oriundos de uma extensa variedade de segmentos e linguagens, como também, envolve uma multiplicidade de públicos a quem se dirigem e são compartilhados os seus trabalhos.

Ao perguntarmos sobre que caminhos possíveis para melhorar as condições de trabalho na Cultura, Ynaê menciona mudanças voltadas principalmente para corrigir as concentrações de recursos e a falta de acesso da sociedade civil às políticas culturais. 


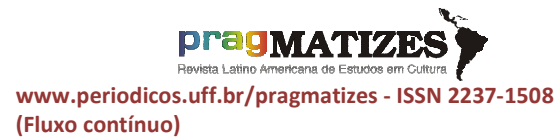
(Fluxo contínuo)
Uma distribuição dos recursos que não privilegie determinados estados a nível federal ou determinados bairros a nível municipal. Uma participação da população na escolha de gestores de instituições, teatros e espaços culturais, assim como a participação da população na escolha da programação desses espaços. Políticas culturais voltadas para pequenos produtores e grupos em vulnerabilidade (MORAIS, 2021).

Além de apontar a necessidade de rever a distribuição dos recursos, que ainda estão concentrados em determinadas cidades, áreas e regiões, destaca a necessidade da população participar do processo de escolha dos gestores das instituições, conforme sugere Ynaê. Tendo em vista que um dos problemas que identificamos, a exemplo do Rio de Janeiro, é que a pasta das secretarias municipal e estadual vêm sendo administradas, sobretudo nos últimos anos, por pessoas que não são oriundas do setor cultural, muitas vezes resultantes de indicações de parlamentares dos órgãos legislativos locais, com fins políticos e eleitorais. Essa é uma questão que já foi levantada nas conferências municipais de cultura do Rio, na direção de garantir que as nomeações de dirigentes que passarem a assumir o comando do órgão gestor da Secretaria Municipal de Cultura do Rio de Janeiro, sejam de fato oriundos do setor artístico-cultural. Para isso, torna-se relevante que atendam ao perfil de preparo e de conhecimento técnico específico na área, permitindo, assim, qualificar e fortalecer a classe trabalhadora cultural, como também, as políticas públicas, programas, gestão de equipamentos e demais ações a serem implementadas na cidade.

Nessa entrevista, Erisvelton de Alencar Santana, 32 anos, que trabalha com publicidade, comunicação visual e redes sociais e é aluno do curso de graduação em Produção Cultural da Universidade Federal Fluminense - UFF, afirma que "apesar de não possuir vínculo empregatício possuo contratos com prazo indeterminado e como geralmente atuo com gestão de mídias e sites a pandemia não afetou tanto quanto outros setores". Assim como Ynaê, ele considera que há um entendimento reduzido da cultura, que está concentrada em eventos, e que a carência de ações e investimentos por parte do governo no mercado cultural 


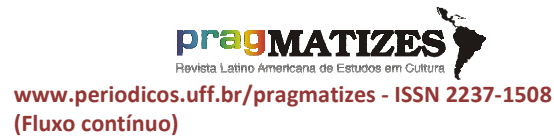
(Fluxo contínuo) é anterior à pandemia, ao contrário da

Coreia do Sul e dos Estados Unidos, conforme exemplifica.

O mercado cultural já era complexo antes da pandemia, pois no Brasil cultura no entendimento popular se resumia a shows e durante muito tempo não possuiu ações significativas do governo para potencializar esse mercado. Em relação ao mundo, esse mercado irá variar dependendo do país que seja analisado, pois há países que entendem a cultura como um mercado altamente importante tanto em questões financeiras quando se trata de disseminar valores culturais, vide o KPOP. (..) No geral são problemas globais, pode ser uma visão micro particular minha, mas pouco se sabe sobre culturas que atravessam sua territorialidade e influenciam o mundo. Temos o exemplo atual do KPOP como grande movimento de popularização da cultura Coreana que impactou o mundo e gerou um retorno para a Coreia do Sul muito grande. Tivemos o cinema Hollywoodiano que vem disseminando os valores norteamericanos há mais de um século, mas ainda assim acredito que poucos países enxergam o potencial da cultura (SANTANA, 2021).

$\mathrm{Na}$ opinião de Erisvelton, há uma desvalorização da cultura brasileira em detrimento da cultura estrangeira e do entretenimento e acredita que o funk ainda pode impactar o mundo.

Acredito que a principal perda se dá devido à má compreensão, por parte da população, sobre o que é cultura. Muitos acreditam que cultura está atrelada ao entretenimento e muitas vezes a hierarquizam desvalorizando toda a produção nacional em detrimento a algo que seja estrangeiro. Embora, com os avanços tecnológicos a cultura popular, tendo o funk como exemplo, em 2020 conseguimos ultrapassar barreiras territoriais e atingir significativamente muitas pessoas. Penso que se fosse investido da maneira correta, poderíamos transformar o Funk em algo $100 \%$ brasileiro e impactar o mundo assim como o KPOP. Essa mudança de olhar do público, conseguir sobreviver sem suporte governamental ao mesmo tempo em que é desvalorizado por ele, se mostra a meu ver como um dos principais desafios de quem trabalha na área cultural (Ibidem, 2021).

Em torno dessa falta de entendimento sobre a cultura, o pesquisador peruano Victor Vich argumenta que implica pensar nela também como um problema cotidiano que muitas vezes é naturalizado ou negligenciado.

Cultura não é uma palavra "boa". Não podemos continuar entendendo-a como algo sempre positivo para a sociedade. Não 


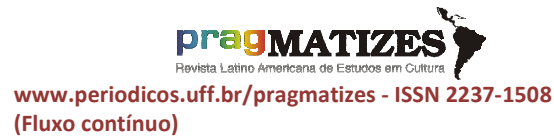
(Fluxo contínuo) podemos continuar entendendo a cultura somente a partir da "aura" das artes, do campo daquilo que é valorizado socialmente. Hoje, devemos entendê-la como laços humanos, estilos de vida, hábitos estabelecidos na cotidianidade mais comum. A cultura disseram-nos - é sempre "o normal". De fato, se pensarmos nela como um problema cotidiano, perceberemos que ela é hegemonia, e que a hegemonia é hoje carreirismo político, corrupção, discriminação em todas as suas formas, consumismo, injustiça social. Nossas sociedades continuam sendo aquelas em que a corrupção se tornou cínica, a desigualdade é naturalizada, o espírito de competição prima sobre qualquer outro, a heterogeneidade cultural só se faz visível como subalternidade e a frivolidade transformou-se em educação sentimental. No entanto, apesar de cotidiano ser uma palavra feia, temos de continuar apostando em uma intervenção na cultura com elementos da cultura. A questão é que devemos fazê-lo com muito mais radicalismo: é preciso conseguir tornar visível o modo como uma forma de poder social se estabeleceu nos hábitos cotidianos. (VICH, 2017, p. 49).

Essas questões problematizadas por Erisvelton não estão dissociadas de um sistema capitalista cujo modelo está concentrado nos ideais neoliberais na economia, com a mínima intervenção do Estado e a centralidade no mercado e na iniciativa privada. Com o excesso de ofertas de bens mercantis e simbólicos que passam a serem absorvidos pelo mercado, principalmente de uma cultura centrada no entretenimento, em grandes eventos, filmes blockbusters e musicais da Broadway que passaram a ocupar as salas dos cinemas e dos teatros brasileiros. Ao mesmo tempo que o Funk ainda é bastante criminalizado, interessa transformá-lo em um produto a ser comercializado. Esse processo de mercantilização da cultura não surgiu agora, Theodor Adorno já falava da indústria cultural nos anos 1940 e desde então, esse processo se aprofundou.

Não à toa, foram introduzidos na cultura os conceitos oriundos do mercado, a exemplo do empreendedorismo para os trabalhadores e o modelo privado das Organizações Sociais, adotado na gestão de museus, teatros, bibliotecas e demais espaços públicos, com a concentração de recursos administrados por empresas como a Fundação Roberto Marinho. Os órgãos gestores municipais e estaduais, inclusive passaram a introduzir a economia criativa no nome 


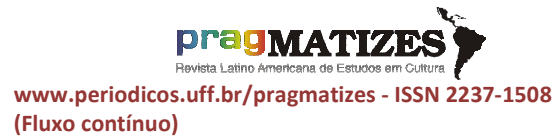
(Fluxo contínuo) institucional dessas pastas, cujo conceito vem sendo adotado também nas políticas adotadas, além das chamadas cidades criativas. Erisvelton aponta propostas de políticas culturas que, em seu entendimento, poderiam fazer a diferença para melhorar as condições de trabalho na Cultura.

Através da criação de políticas culturais que deem suporte a ações e movimentos populares, não é ser sustentado pelo governo como alguns podem pensar, é ter suporte. Existem centenas de músicos que se apresentam nas ruas por não existirem palcos para shows gratuitos no país. Centenas de artistas plásticos expõem suas pinturas, esculturas, artesanatos em calçadas por não haver uma galeria pública onde pudesse ser feita a comercialização das obras. Ou ainda, não existe um circuito cultural de valorização de produções locais e disseminação de produtos por todo o território brasileiro, pois pouco sabemos sobre o que é produzido em outras regiões, visto que 0 governo foca seu olhar na região sudeste negligenciando as outras quatro regiões (Ibidem, 2021).

\section{Essa reduzida visão}

concentradora, desigual e de mal uso da cultura, acaba por ser utilizada para fins políticos e interesses individuais, mercadológicos e hegemônicos, acirrando as desigualdades e as opressões. Para fazer uma mudança através das políticas públicas, conforme sinalizam Erisvelton e Ynaê, implica ampliar o olhar acerca da sociedade que vivemos, reorganizar o cotidiano e construir uma nova hegemonia.

Nesse sentido, sustento que as políticas culturais devem se concentrar em mostrar como surgiu a ordem que temos. Para transformar a realidade, é preciso primeiro mudar a maneira de olhar para ela. Acho que as políticas culturais devem apontar para isso. Mais do que produzir um novo tipo de dever, a questão é gerar uma imagem que nos faça ver o tipo de sociedade que temos. [...] $O$ objetivo das políticas culturais deve então consistir na tentativa de reorganizar o cotidiano, de contribuir para a construção de uma nova hegemonia. Agora, o que é o cotidiano? Poderíamos dizer que é o mundo da inércia, dos hábitos estabelecidos, do senso comum existente, das maneiras estabelecidas do fazer. Contudo, sem dúvida, trata-se também do espaço da criatividade, da agência, do lugar onde pequenas mudanças sociais poderiam acontecer. O cotidiano é sinônimo de cumplicidade, mas também de resistência; é inércia, mas também a possibilidade de transgressão (VICH, 2017, p. 49).

Além de aprofundar o significado de cotidiano, Victor Vich lança o desafio de transformá-lo, na medida 


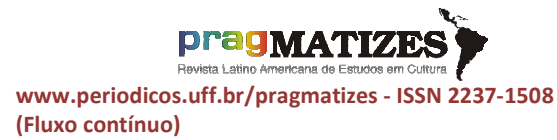
(Fluxo contínuo) em que uma verdadeira transformação social não pode ser concebida como externa ao cotidiano, mas como uma mudança fundamental na vida diária. O que significa isso? "Significa que as políticas culturais devem ser sempre transversais e estar articuladas com políticas econômicas, da saúde, da habitação, do meio ambiente, de gênero, de segurança cidadã, do combate à corrupção" (VICH, 2017, p. 50). Segundo ele, as políticas culturais não estão articuladas com esferas fora de si mesmas, o mais provável é que a cultura continue sendo vista como entretenimento ou como assunto para especialistas (VICH, 2017).

Wildson de Andrade França, 40 anos, é ator, produtor e palhaço, atua na área de Artes Cênicas, na cidade de Duque de Caxias, na Baixada Fluminense, fazendo apresentações em festas, teatros, circos, mas principalmente nos trens da Supervia, afirmando que já se viu muitas vezes em estado de precariedade, "foi me apresentando nos trens que ocorreu a mudança, mas hoje por conta da Covid-19 tive que me ausentar dos trens por conta das aglomerações". Ao avaliar o mercado de trabalho na Cultura no Brasil, ele acredita que as principais precariedades estão nas periferias e no interior do país, assim como, na falta de reconhecimento e entendimento acerca da Arte Pública como fazer artístico.

É um mercado abrangente, mas têm muitas precariedades aqui no Brasil, uma delas é ausência de equipamentos culturais públicos nas periferias e interiores. Outra precariedade é a falta de diálogo e compreensão sobre a questão da Arte Pública, como fazer artístico e manifestação. Existe um mercado na arte pública uma movimentação, porém, não é levada em consideração no Brasil (FRANÇA, 2021).

Com o seu Palhaço Will Will, Wildson França criou o espetáculo "Will Will Conta Benjamin de Oliveira", que rememora a trajetória de Benjamin de Oliveira, o primeiro palhaço negro do Brasil, a partir do olhar de Will Will, um palhaço negro dos dias atuais, que enquanto conta a história de seu ancestral, identifica semelhanças com ele e com sua trajetória. Wildson realizou a Semana Benjamin de Oliveira, na Baixada Fluminense, convidando palhaços pretos para homenageá-lo. "A ideia é manter viva a memória de Benjamim como referência. $E$ é também lançar ao público questões como a ausência 


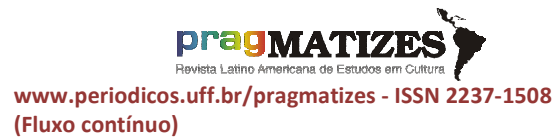
(Fluxo contínuo) de palhaços pretos na palhaçaria e fomentar a criação de uma rede para ações conjuntas e contínuas", revela ${ }^{2}$.

De fato, o Circo é um dos segmentos das Artes Cênicas que mais enfrenta dificuldades com a ausência, ou a burocratização, de espaços públicos e de infraestrutura adequadas para montar e apoiar os circos nas zonas urbanas e rurais das cidades. A arte circense praticada nas lonas, ou através da Arte Pública, conforme é realizada por Wildson nos trens da Supervia, precisa de políticas públicas e apoio de editais para desenvolver as suas atividades. Ainda mais nesse momento em que os artistas de rua não conseguem mais expor as suas artes no espaço público e interagir no contato humano, nas praças, nos trens, no metrô, nas barcas, nas escolas, se vendo obrigados a recolherem os seus chapéus de sobrevivência.

Ele aponta as principais perdas, avanços e desafios para as trabalhadoras e os trabalhadores da Cultura, além de considerar que a Lei

\footnotetext{
${ }^{2}$ Em Redação da Baixada, Rio de Janeiro, 10/6/2020. Disponível em:: sitedabaixada.com.br/cultura/2020/06/10/palha cos-pretos-da-baixada-fluminensehomenageiam-benjamim-de-oliveira/).
}

de Emergência Cultural Aldir Blanc representa a necessidade de manter esse tipo de dotação orçamentária, como também, trazer a Arte Pública para a centralidade do debate.

Menos equipamentos culturais, menos políticas culturais, sucateamento órgãos importantes como a Ancine e seus editais. Falta de editais com segmentos mais abrangentes como artes afro-brasileiras, produções feitas por mulheres, etc. Creio que a LAB foi uma ótima forma de saber quantos somos quem somos e abrir uma grande discussão sobre as Secretaria de Cultura nos estados e municípios do Brasil. E acho desafio abrir uma grande discussão sobre arte pública e ser contínua a dotação orçamentária com advento da LAB (Ibidem, 2021).

Ao perguntar sobre que caminhos possíveis para melhorar as condições de trabalho na Cultura, Wildson apresenta algumas das prioridades, que segundo ele, exigem maior comprometimento por parte dos gestores e reitera a potência da Arte Pública.

Gestores que tenham conhecimento e comprometimento com a cultura, criação de equipamentos, ocupação de espaços ociosos e públicos, desburocratização dessas ocupações. Ampliação de leis de incentivo, editais e 


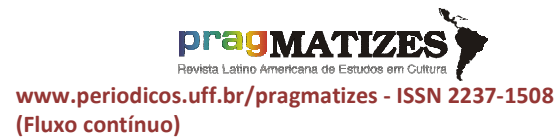

emendas para cultura. Creio que a arte pública é uma das grandes salvações como forma de vivência, sobrevivência e resistência ante tantos retrocessos neste país. Temos muitos gargalos que vão continuar infelizmente, mas diminuindo o contato do artista com o público nesse momento pode solucionar muitas questões (Ibidem, 2021).

Sobre Wildson ter ressaltado que as principais precariedades estão nas periferias, trazemos algumas reflexões feitas pela socióloga Lívia de Tommasi, que pesquisa periferias, juventudes, culturas urbanas, empreendedorismo e trabalho precário. No trabalho de pesquisa de caráter etnográfico realizado na Cidade de Deus, no período de pacificação das favelas no Rio de Janeiro, Tommasi disse ter se deparado com muitos projetos que falavam em empreendedorismo, no momento em que ainda se falava muito pouco sobre isso. $\mathrm{E}$ começou então uma efervescência, com cursos de formação, debates, financiamentos, em particular, nesse âmbito da arte e da cultura como ideia de financiamento e remuneração das atividades, e muitos projetos de Organizações Não Governamentais que antes tinham a ideia de salvação, como arte para combater a guerra. E menciona também um fundo municipal que tornou-se referência nesse campo com - programa de Valorização das Iniciativas Culturais (VAI), focado nas juventudes da periferia, criado em 2003, em São Paulo, pela Lei Municipal $n^{\circ} 13.540 / 2003$ e, que em 2014 ganhou uma segunda modalidade por meio da Lei Municipal 15.897/2013. Ações, ocorridas fortemente em São Paulo e no Rio de Janeiro, que buscavam a visibilidade e uma oferta de possibilidades de financiamento, como também, o caráter instrumental dessa celebração e desse suporte no âmbito da chamada pacificação, de acordo com ela, trazendo a ideia de que se poderia integrar os pobres à cidade através do mercado. Nesse cenário, ocorreram alterações no mercado de trabalho com a figura do Microempreendedor Cultural.

Por isso, esse estímulo à formalização do trabalho cultural, via Microemprendedor Cultural $\mathrm{MEl}$, tinha essa perspectiva, de tornar os informais como contribuintes, e, ao mesmo tempo, garantir a eles alguns direitos através dessa figura jurídica. Mas para uma parcela 


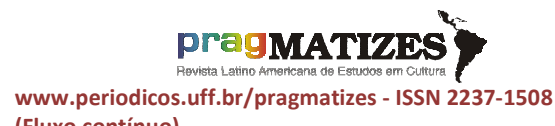
(Fluxo contínuo) desses jovens é também uma forma de se sustentar economicamente. E é por isso que eu digo que o trabalho nessa área pode ser considerado paradigmático do ponto de vista das transformações que ocorreram nos últimos decênios no mundo do trabalho, quando para fazer frente a uma classe enorme de desemprego provocada pela desestruturação produtiva com a globalização dos mercados, a deslocalização da produção, a partir dos anos 70 , flexibilidade e precarização foram apontadas como as únicas saídas possíveis (TOMMASI, 2020).

$\mathrm{Na}$ entrevista feita com José Carlos Rosa Miranda, 35 anos, que trabalha no segmento de Teatro, como ator e produtor teatral, ele afirma que atualmente não está em estado de precariedade, mas, "passei por situações de baixa produção, ou seja, os trabalhos estavam bem escassos, fora a concorrência que é muita e infelizmente as indicações entram no lugar das qualidades muitas vezes". E considera que o mercado de trabalho da Cultura no Brasil e no campo global está "muito ruim, infelizmente não soubemos aproveitar a efervescência da produção cultural que esteve muito potente até 2013, e hoje com o atual cenário político, perdemos muito, mas somos fortes e vamos vencer esse marasmo de horrores que o país se encontra".

$\mathrm{Na}$ opinião de José Carlos, estamos vivendo dois momentos contrastantes para a Cultura, da efervescência passamos para um desmonte. Depois de muitos avanços alcançados no Brasil, principalmente durante o governo do presidente Luis Inácio Lula da Silva, no período de 2003 a 2011, com uma política pública que conferiu musculatura institucional para a pasta da Cultura, nas gestões dos ministros Gilberto Gil e Juca Ferreira, estamos passando por um acelerado desmanche das políticas de Estado de âmbito federal, com profundos impactos causados na gestão pública de Cultura, sobretudo no governo do presidente Jair Messias Bolsonaro, a partir de janeiro de 2019. Além de cortes, contingenciamentos de recursos, instalou-se uma guerra cultural, com censuras e perseguições aos artistas. Embora esse avançado processo de desinstitucionalização do setor e das políticas públicas tenha iniciado desde o golpe decretado em 2016, com a retirada da presidenta Dilma Rousseff, que resultou na extinção do Ministério da Cultura, uma das primeiras medidas tomadas por 


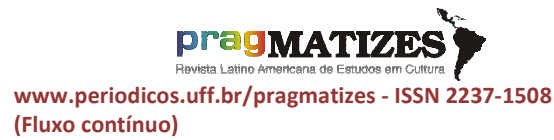

Michel Temer ao assumir o governo. Sobre os problemas vividos no mercado de trabalho, José Carlos destaca a mesma fragilidade apontada por Erisvelton, afirmando que a cultura estrangeira é mais valorizada do que a brasileira, principalmente as atividades de pequeno porte realizadas em áreas periféricas, a exemplo do Teatro, conforme Wildson já havia mencionado.

Creio que seja nível Brasil, até porque 0 povo brasileiro infelizmente valoriza pouco a nossa cultura, exceto algumas manifestações que ultrapassam da barreira da cultura, como o Carnaval, por exemplo, e outros eventos de grande porte, que fogem da essência cultural. $O$ teatro, por exemplo, realizado por pequenas produções ou grupos de bairros periféricos são pouco valorizados, e muitas pessoas que tem a mínima condição de sobrevivência, prefere assistir um espetáculo da Broadway do que ver uma manifestação artística de um grupo da periferia. Com isso, o jogo político ganha força e não investe no principal alimento da alma do público a arte (MIRANDA, 2021).

Além de falar, assim como os demais entrevistados, dos problemas e desafios que precisam de investimento, no que se refere aos equipamentos culturais e à infraestrutura, José Carlos ressalta a importância de garantir o acesso às pessoas com deficiência e dialogar com as escolas públicas.

O desmonte dos equipamentos culturais, a falta de investimento em infraestrutura, melhorias simples para acolher os espetáculos, acolher os públicos principalmente os que são portadores de alguma deficiência, vivendo atualmente um cenário muito triste na cultura. [..] Investir em infraestrutura, investir em grupos populares para que as principais

manifestações artísticas

presentes em nosso país não fiquem obsoletas. Investir em fomento público direto para grupos artísticos possam desenvolver produtos artísticos em suas comunidades/bairro. Criar projetos que possam dialogar com escolas públicas, fazendo com que o artista possa ocupar profissionalmente (Ibidem, 2021).

Essa necessidade, mencionada por José Carlos, de aperfeiçoar e criar condições de mobilidade aos equipamentos onde ocorrem os espetáculos culturais, a fim de tornálos habilitados e adaptados para o acesso de suas dependências internas e externas, tem sido discutido nos fóruns e conselhos culturais municipais e estaduais. Sendo necessário, nesse caso, ampliar os recursos financeiros destinados às políticas de 


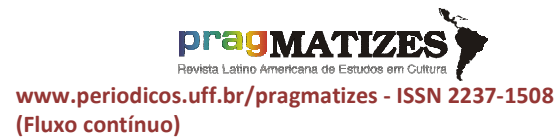
(Fluxo contínuo) acessibilidade cultural, mas não somente voltadas para o público, como também, aos artistas, entre outras pessoas com mobilidade reduzida.

Ao apresentar o seu histórico de trabalho nas Artes Cênicas, o ator titeriteiro Gabriel Bezerra de Melo Júnior, 58 anos, que reside na cidade do Rio de Janeiro, menciona que em sua trajetória tentou buscar outras profissões e a ajuda de familiares foi decisiva para que conseguisse fazer seus trabalhos artísticos.

Sou registrado como ator titeriteiro no meu DRT, obtido no Sindicato de Artistas e Técnicos de São Paulo por volta de 1998, comprovando minhas atuações. Portanto, nas artes cênicas como ator marionetista em espetáculos de diversão. Trabalhei como manipulador em programas de TV, como TV Colosso - Rede Globo. Como muitos colegas de profissão, passei por altos e baixos durante grande parte faz minha carreira. Muitas vezes tentei praticar outras profissões fazendo cursos, mas sempre retomava aos trabalhos artísticos. Tive apoio de familiares e esposas (MELO JUNIOR, 2021).

Gabriel Bezerra ressalta as

políticas públicas implementadas nos períodos de gestões dos expresidentes Luiz Inácio Lula da Silva (2003 a 2010) e Dilma Rousseff (2011 a 2016) como um salto de qualidade que, em seu entendimento, foram determinantes para alavancar a sua trajetória no trabalho com a Cultura.

No mundo tivemos movimentos artísticos relevantes e com muita influência. No Brasil tivemos um salto muito grande de qualidade e oportunidades através das políticas públicas dos períodos Lula e Dilma, onde trabalhei incessantemente em circuitos SESI, SESC e SENAI. Depois passei por muitas dificuldades, inclusive pessoais precisando cuidar da minha mãe idosa e demente, o que afastou do front dos palcos (Ibidem, 2021).

Nesse contexto dos avanços políticos e institucionais realizados desde o primeiro mandato do presidente Lula e na gestão da presidenta Dilma Rousseff, mencionados por Gabriel Bezerra, sobretudo nas gestões dos ministros Gilberto Gil e Juca Ferreira, destacamos o papel do Plano Nacional de Cultura (PNC), instituído pela Lei n.12.343/2010, com validade para 10 anos. Formulado com a ideia de apresentar um planejamento de longo prazo, a formulação do PNC contou com a participação da sociedade civil, a partir de consultas nacionais e regionais por meio de fóruns e conferências realizados pelo país. 


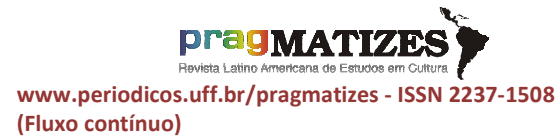
(Fluxo contínuo)
Além do Sistema Nacional de Informações e Indicadores Culturais (SNIIC) e o Plano de Economia Criativa. E ainda, a aprovação e a regulamentação do Vale-Cultura, um benefício ligado ao Programa de Cultura do Trabalhador, cujo objetivo era garantir acesso e incentivo aos programas culturais brasileiros através do auxílio de $\mathrm{R} \$ 50,00$, oferecido pelas empresas que faziam parte do Programa e era fornecido aos funcionários de carteira assinada. Essa mudança estruturante de uma política pública, iniciada em 2003 , que conferiu musculatura institucional para a pasta da Cultura, foi desmontada a partir de 2016 e definitivamente extinta em 2019.

A gestão do Ministério da Cultura iniciada em 2003 resultou na implementação do Sistema Nacional de Cultura, baseado no Sistema Único de Saúde (SUS), que é uma referência nacional e mundial, que estabeleceu o pacto federativo, entre estados, união e municípios. Para formular uma política com a sociedade civil, a partir de um amplo processo de diálogo e debates em fóruns, préconferências, conferências municipais regionais, estaduais, nacionais que resultaram na elaboração de planos e na criação de conselhos representativos. Além de outras políticas culturais, como $\mathrm{O}$
Programa Cultura Viva com Pontos de Cultura, Colegiados Setoriais, Fundos Culturais, que nesse momento percebemos que estão se esfacelando e com profundos cortes e suspensão dos editais e contingenciamento no orçamento da pasta (RODRIGUES; PARDO, 2020, p. 239).

Gabriel Bezerra observa que os problemas locais de perdas, estado de calamidade e precarização do trabalho no setor cultural não estão dissociados do sistema capitalista, que se alimenta da exploração, opressão, destruição das políticas públicas e da cultura brasileira que estão sendo feitas na política ultraliberal do presidente Jair Bolsonaro. Em contraponto, ele menciona que a Lei de Emergência Cultural Aldir Blanc acabou aproximando os artistas que passaram a se unir pelas redes.

Nossos problemas são locais mais concretamente falando, porém, oriundos de uma escala global aonde se insere a crise do capitalismo, o ultraliberalismo e a ascensão da extrema direita no mundo e a crescente concentração de renda no mundo. A destruição de toda e qualquer ação que afirme a cultura brasileira, qualquer coisa que seja cultura, nossa identidade. $O$ preconceito, a imbecilidade, a destruição de políticas culturais e verbas (vide PEC dos infernos)! Além da 


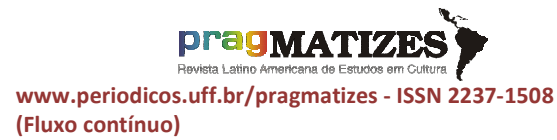
(Fluxo contínuo) permanência do genocida Jair Bolsonaro e a política ultraliberal apoiada pela elite mais perversa que existe em todo o planeta. A pandemia atrapalhou bastante, mas nos uniu pelas redes, uniu artistas de todas as tribos e conseguimos gerar $\mathrm{O}$ maior legado desta época que foi a $L A B$ (MELO JUNIOR, 2021).

Gabriel menciona a destruição das políticas culturais e demais perdas, com o que chamou de "PEC dos Infernos", apresentada por Michel Temer. Trata-se Proposta de Emenda Constitucional (PEC) 55, conhecida como a PEC do Teto dos Gastos, e também como a "PEC do Fim do Mundo", que congela os investimentos públicos durante 20 anos, inviabilizando também o Plano Nacional de Educação (PNE), criado em 2014 pelo governo da presidenta Dilma Rousseff, que previa aumentar o valor dos investimentos na educação pública gradativamente em um período de dez anos. O filósofo e pedagogo Demeval Saviani, ao criticar as medidas e o governo de Temer, com essa PEC do Teto dos Gastos, que, segundo ele, inviabilizou a educação pública no país, afirma: "O que provocou o golpe foram os interesses econômicos do sistema financeiro, daí o foco na dívida e nas contas públicas, para fazer caixa, para fazer o superávit primário, para o pagamento dos bancos" 3 .

Esse acelerado desmonte, continuado na política neoliberal de Jair Bolsonaro, resulta em cortes no orçamento, suspensão de editais e nas privatizações das empresas estatais, dentre outras ações que estão impactando $\mathrm{O}$ setor cultural. $\mathrm{Na}$ contramão, Gabriel considera que a pandemia aproximou a classe artísticacultural em torno da Lei de Emergência Cultural Aldir Blanc, Lei $n^{\circ}$ 14.017, de 29 de junho de 2020. Apresentada pela Comissão de Cultura da Câmara dos Deputados, e aprovada em resposta aos severos impactos sociais e econômicos decorrentes da pandemia da Covid-19, naquele que tornou-se um dos setores mais afetados pelas restrições de circulação impostas à população: o setor cultural. Com o fechamento, do dia para noite, de casas de espetáculos, museus, centros culturais, entre outros, além do cancelamento de apresentações

\footnotetext{
${ }^{3}$ Em Mauro Ramos. Brasil de Fato, Política, São Paulo (SP), 08 de Dezembro de 2017. Disponível em: https://www.brasildefato.com.br/2017/12/08/pe c-do-teto-dos-gastos-inviabilizou-a-educacaopubica-no-brasil-diz-dermeval-saviani).
} 


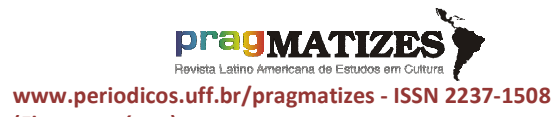
(Fluxo contínuo) artísticas, feiras e exposições, inúmeras trabalhadoras e trabalhadores da cultura viram-se subtraídos da renda responsável pela sua subsistência.

A Lei de Emergência Cultural Aldir Blanc (Lei 14.017/2020), batizada em homenagem ao escritor e compositor que veio a falecer em maio de 2020, em função do coronavírus, que resultou numa ampla mobilização e campanha nacional do setor cultural brasileiro, destinou $\mathrm{R} \$ 3$ bilhões ao setor cultural, na forma de renda emergencial, subsídio para manutenção de espaços culturais e editais e chamadas públicas. Para esse ator, criador de títeres e marionetes, a quebra da espinha dorsal do país exige resistência, engajamento e reinvenção.

A resistência através de maior engajamento de artistas, gestores e políticos na luta pelo restabelecimento de todo o conjunto de experiências positivas de sentir no passado, com a experiência que estamos vivenciando no momento e o fortalecimento do campo progressista, como único meio de se reconstruir o que já não existe. É desanimador. Quebraram a espinha dorsal do nosso país e levaremos muito tempo pra restabelecê-la. Não é para a nossa geração. Mas é ela quem deve continuar a resistir e se reinventar (MELO JUNIOR, 2021).

Nessa entrevista, a atriz Célia Maracajá, 63 anos, nascida em Belém do Pará e residente na cidade do Rio, fala de suas várias ações para manter a sobrevivência, implicando no amor à arte e na militância política para trabalhar com Teatro e Cinema.

Tenho trabalhado como atriz em teatro e cinema em projetos que são frutos de editais, recebendo cachês, por vezes razoáveis e outras vezes fazendo por amor à arte e militância política. O mesmo ocorre em relação a trabalhos que dirijo tanto no cinema como no teatro. Quanto às formas de sobrevivência, realizo outras ações podendo citar: ministro oficinas de interpretação para cinema em diversas instituições, como por exemplo, a Escola de Cinema Darcy Ribeiro. Faço também doces e geleias de frutas regionais. Todos com sabor do Pará (MARACAJÁ, 2021).

Célia Maracajá atribui como responsável pela catástrofe sanitária e as perdas dos direitos dos trabalhadores, a situação de crescente precariedade dos artistas que acirrou nos últimos dois anos, assim como o desmonte do Ministério da Cultura e da Ancine, quem nomeou de "inimigo do povo brasileiro", que tem nome e 


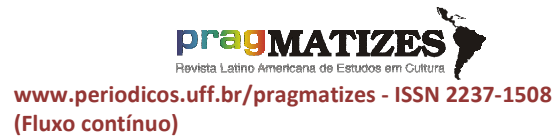
(Fluxo contínuo) sobrenome. Mas que ela disse ter aprendido com os mestres da cultura popular a não pronunciar o nome do inimigo.

Temos vivido situações de precariedade em diversas ocasiões, como a maioria dos nossos artistas que sofrem nesse país, principalmente nos últimos dois anos, enfrentando um desgoverno que mergulhou o Brasil numa das maiores tragédias política e humanitária dos últimos tempos, ocasião em que ocorreu também o desmonte do Ministério da Cultura e da Ancine. Projetos já aprovados, infelizmente foram invalidados. Em função da pandemia esse quadro se agravou. Tenho vivido do auxílio emergencial, que também está findando. Uma coisa é certa, o inimigo do povo brasileiro tem nome e sobrenome: Jair Bolsonaro (não gosto nem de pronunciar esse nome, pois aprendi com os mestres da cultura popular que não se pronuncia o nome do inimigo). Ele vem retirando o direito dos trabalhadores, Ele vem entregando o país. Ele é responsável pela maior catástrofe sanitária que estamos vivendo. Ele deveria ser julgado por um tribunal internacional por crimes contra a humanidade (Ibidem, 2021).

A atriz diz que a sua situação de sua precariedade e dos demais artistas não começou agora. Porém, estamos com um aumento significativo de desemprego e decisões políticas que fragilizaram os vínculos no mundo do trabalho, como a reforma trabalhista, a lei da terceirização e a reforma da previdência, com um mercado desregulado e a perda dos direitos básicos e de aposentadoria. Em contraponto à catástrofe e ao que chamou de desmonte da Cultura, - em que se desfez a pasta do Ministério da Cultura e de suas fundações vinculadas: Fundação Nacional de Artes (Funarte), Fundação Cultural Palmares, Fundação Biblioteca Nacional, Fundação Casa de Rui Barbosa, como também, a Ancine, que é uma autarquia vinculada ao MinC desde 2003, cujos editais foram censurados e suspensos, - Célia Maracajá também destaca, assim como outros entrevistados, apenas um período de avanço no setor cultural, ocorrido na gestão do ministro Gilberto Gil e do presidente Luís Inácio Lula da Silva, em que houve uma consistente política voltada para o Cinema.

O Brasil é dono de uma riqueza cultural impressionante. Vou salientar aqui apenas o avanço que tivemos em um dos segmentos da cultura, durante a gestão do Ministro Gilberto Gil, no governo Lula. O Gil que é um artista da música, mas pensa a cultura como o grande alimento, 


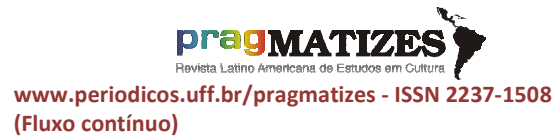
(Fluxo contínuo) como a arte de tornar possível o impossível, juntamente com uma equipe, onde podemos destacar o Orlando Senna, criou uma política voltada para o cinema que ampliou, qualificou e democratizou a produção cinematográfica brasileira. De norte a sul nesse país se produziu maravilhas e se firmou parcerias além fronteiras com os nossos irmãos latino americanos (Ibidem, 2021).

Ela também considera que a Lei de Emergência Cultural Aldir Blanc representou uma grande conquista para o setor cultural e refere-se às palavras resistência e reinvenção, usadas por Gabriel Bezerra (de Melo Junior), para reverter esse quadro de destruição, em que a rebelião e a guerrilha cultural são as únicas alternativas possíveis.

Os problemas vivenciados pela cultura no nosso país são locais, face à uma destruição dos instrumentos que impulsionam a vida, o fazer cultural. Mas existe resistência também. Os artistas se reinventam. A criação da lei Aldir Blanc é uma constatação disso. Criada pelo Congresso Nacional, por propostas dos artistas, revelou que ainda vale a pena lutar e criar formas para manter viva a chama que jamais se apagará. A criatividade e a esperança de que a barbárie não triunfará. $O$ único caminho possível é o da rebelião e o da constante guerrilha cultural (MELO JUNIOR, 2021).
Sobre as condições de trabalho que levantamos nessa pesquisa, a atriz, bailarina e professora Daphne Madeira, 48 anos, que atua no segmento da Dança, acredita que as mudanças ocorridas com a suspensão das atividades e aulas presenciais nesse período de pandemia, impactaram ainda mais em suas condições já precárias de sobrevivência na Cultura, causando danos também de ordem física e psicológica.

Eu sou atriz, bailarina e professora. Atualmente, estou lecionando técnicas somáticas (Pilates, Eutonia, Laban, Dança) online para alunos particulares, e também sou professora da Escola Angel Vianna, mas neste semestre não estarei em sala de aula (online) pois a turma decidiu que só voltará presencialmente. Diante deste quadro, as condições de sobrevivência são bastante precárias, na verdade não tenho carteira assinada como professora, e como bailarina, coreógrafa ou diretora de movimento de teatro são raros os trabalhos remunerados, e isto se agravou muito no período da pandemia. Assim, nos coube a tarefa (ou sempre nos caberá?) de se reinventar a cada momento. Não muito raro estou em momentos que a precariedade se agrava, ela sempre está potencialmente presente na minha vida, já que 


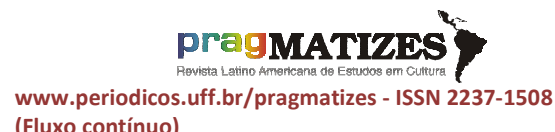
(Fluxo contínuo)

por modas, como por exemplo, a música sertaneja e o teatro de grandes musicais. O artista gira entre esse mercado de grandes produtores, altas verbas $\mathrm{e}$ investimentos, mas seus cachês ainda são bem abaixo da linha de estabilidade financeira. Acredito que a crise na cultura é um fenômeno mundial, onde outras áreas de atuação sempre foram mais valorizadas. No caso do Brasil, país do terceiro mundo, que vive entre a urgência de sobreviver em todas as direções, a arte se encontra agonizando, e este panorama se agravou com o governo de Bolsonaro que não valoriza a educação e a cultura (Ibidem, 2021).

Daphne Madeira, assim como os demais entrevistados, problematiza acerca desse mercado concentrador de recursos em grandes produtores, embora com baixos cachês. $E$ procura destacar as principais perdas, avanços e desafios para os trabalhadores e as trabalhadoras da Cultura nesse momento. "As perdas são constantes ainda mais neste momento O mercado é sempre ditado por grandes negociações, seja no âmbito político, seja no âmbito financeiro, ou artístico. Assim, a arte acaba por se encontrar tensionada entre produto $\mathrm{e}$ processo. E o que vale é ditado pelo mercado do Grand Mond, cada vez mais alguns processos artísticos caem de moda, e outros sobem de cotação. A dança tem atualmente pouquíssimo investimento perante as outras artes como o teatro e a música. $\mathrm{E}$ mesmo estas são tensionadas pandêmico, o avanço foi garantir a implementação da Lei Emergencial Aldir Blanc, e o maior dos desafios é garantir através de políticas públicas novos modos de gerar trabalho $e$ garantias de renda para os artistas e trabalhadores da cultura", afirma. Ao perguntar sobre que caminhos 


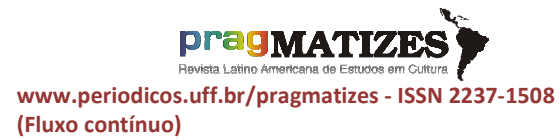
(Fluxo contínuo)

que aceite o experimental. E que o público vem a ser menor. Isso requer políticas diferentes. Sem o experimental não evoluímos como linguagem (MILFOND, 2021)

união a partir das participações da sociedade civil, novas leis que garantam um mínimo de condição econômica mensal para os artistas em geral. E estar numa organização não hegemônica suficientemente forte para participar e criar novos caminhos em editais, leis, etc".

Esse estado de constante precariedade do trabalho no campo artístico-cultural, se expressa também na fala da atriz Denise Milfont, 58 anos, ao dizer que nunca ganhou dinheiro trabalhando com o Teatro. E, da mesma forma que Daphne Madeira e os outros artistas entrevistados, ela pontua que o entretenimento ocupa mais espaço e apoio em relação às artes, principalmente $\mathrm{o}$ trabalho de pesquisa experimental, exigindo serem adotadas políticas diferenciadas.

Sou atriz. Vivo de gerenciar uma residência de artistas. E quando tem trabalho, mas com o teatro nunca ganhei dinheiro. Enfrentei precariedade, mas tive ajuda da família. A cultura sempre foi para mim dividida em duas esferas. A arte $\mathrm{e} O$ entretenimento. $\mathrm{O}$ entretenimento sempre foi e será mais rentável e o trabalho de pesquisa que requer um público
Denise toca num dos gargalos que identificamos no setor cultural, que costuma concentrar os recursos nas ações e editais, mais voltados para os resultados, nesse caso, para a produção e também a circulação, em detrimento dos seus processos de construção, deixando, portanto, de considerar a formação, a pesquisa e o trabalho experimental, que implicariam em políticas diferenciadas. E para apoiar pesquisas, cursos, ciclos e seminários, oficinas de formação, cujo pensamento crítico criador já vem sendo profundamente censurado, perseguido e penalizado pela atual gestão do presidente Jair Bolsonaro, com a suspensão de atividades e de recursos que já estão por muito tempo paralisados. A cadeia produtiva da cultura, por conta de desenvolver-se a partir das dimensões simbólica, cidadã e econômica, significa passar pelos processos de criação, produção, circulação, formação, distribuição, intercâmbio, difusão, acesso e fruição de bens, obras, 


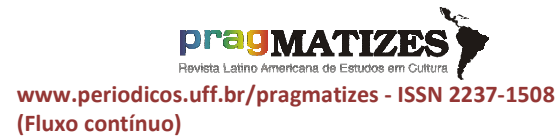
(Fluxo contínuo) espetáculos, filmes, livros, atividades culturais e expressões artísticas e culturais de uma ampla diversidade de segmentos.

Assim como os demais entrevistados, Denise Milfond também faz uma crítica ao governo atual que desconsidera a Arte e a Ciência, tornando ainda mais dramática as condições de trabalho para os artistas. Dentre as perdas, ela problematiza os impactos das tecnologias apontando a necessidade de se repensar o formato de apresentações presenciais.

Quanto ao mundo global acho que cada país tem sua própria política. Não há trabalho para todos artistas em lugar nenhum do planeta. São muito poucas oportunidades para dividir em tantos profissionais. No Brasil particularmente o momento é desanimador, pois enfrentamos um governo negacionista, anticiência e antiarte. As perdas já estão ocorrendo há algum tempo na minha opinião. São as referências de qualidades serem baseadas pelo número de seguidores numa mídia social. Penso que isso gerou uma equidade nociva que é irresponsável no setor cultural. Hoje em dia qualquer um vira artista e arte demanda talento e vocação. Arte virou algo sem conteúdo $\mathrm{Na}$ sua maioria, os avanços que conseguimos alcançar foi maior número de público, mas sujeitos a um total descaso e o desafio será permanecer ativo nesta pandemia. Neste momento requer entender de uma forma coletiva que o presencial deve ser reformulado (Ibidem, 2021).

Para além de um governo negacionista, que vem promovendo uma guerra cultural e o esvaziamento principalmente das políticas públicas alavancadas nos últimos quinze anos, sem dúvida, uma das mudanças significativas que estamos atravessando na atualidade, sinalizadas por Denise Milfond, referem-se às etapas de comunicação e fruição na cadeia produtiva da cultura. Diante da obrigatória necessidade de evitar as aglomerações e o contato presencial, a fim de evitar o contágio de covid no período de pandemia, a única maneira de apresentar, transmitir e compartilhar as criações artísticas passou a ser o formato virtual, pelas plataformas online, nas redes sociais. Essa situação acirrou ainda mais os impactos das tecnologias digitais sobre as artes presenciais, em tempos marcados por uma cultura digital que vem mudando de forma significativa os comportamentos na sociedade, a partir de relações interpessoais cada vez mais mediadas pelo computador, a 


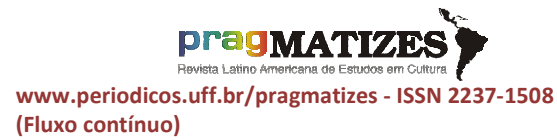
(Fluxo contínuo) rede de internet e outros aparelhos digitais. Uma mudança que implica repensar, por exemplo, o Teatro como linguagem, já que é uma arte cênica e prescinde da situação de co-presença, e como experimenta o tempo da comunicação virtual mediada pelas tecnologias e o computador. Para se pensar sobre o que virou Teatro, qual o público com quem irá dialogar, que formas de comunicação a serem estabelecidas e como isso se reflete na cena contemporânea, no Teatro como Trabalho.

Já 0 entrevistado Stanley Livingstone Whibbe, 68 anos, depois de exercer a função de ator da Companhia Experimental do Sesc TESC, em Manaus, e trabalhar por cerca de 30 anos no Rio, na Fundação Nacional de Artes - Funarte do Ministério da Cultura, onde foi inclusive coordenador de Teatro, nos últimos anos ele passou a atuar no segmento de Elaboração e Produção de Projetos, com a prestação de serviços, através da microempresa, Stanley Projetos Empresariais Ltda. Porém, afirma que "a empresa encontra-se com muita dificuldade para se manter ativa. Modos de enfrentamento: empréstimos bancários para pagar as contas e diversificação do portfólio". Ele considera que trata-se de um quadro tão dramático no mercado de trabalho na Cultura que muitos profissionais estão sendo obrigados a deixar o setor. $E$ também pontua que essas grandes perdas se deram nos últimos dois anos, portanto, essa situação de perdas é anterior ao período de pandemia.

As empresas estão sendo fechadas, os profissionais estão se empregando em empresas de publicidade. Conheço profissionais que foram preparados ao longo de muitos anos para atuar com profissionalismo no setor, mas no momento estão vendendo instalação de energia solar. Outros viraram vendedores da "Natura". Regredimos 10 anos em dois (WHIBBE, 2021).

Assim como os demais entrevistados, Stanley atribui a responsabilidade pela dramática precariedade vivida pelos profissionais da Cultura, à má gestão de Jair Bolsonaro que assumiu o governo nesses últimos dois anos. Com a extinção definitiva da pasta da Cultura, em 2019, no governo Bolsonaro, o Ministério da Cultura transformou-se numa Secretaria Especial da Cultura, 


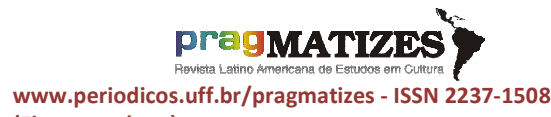
(Fluxo contínuo) atualmente subordinada ao Ministério do Turismo. Além de perder a musculatura institucional para manter o órgão gestor e a sua capacidade para formular, executar e dar continuidade às políticas pactuadas com a sociedade e com os entes federados municipais e estaduais, instalou-se uma guerra cultural implantada nesse governo, cuja ideologia vem sendo defendida pelas pessoas nomeadas ao assumirem a gestão, a exemplo dos posicionamentos adotados por Regina Duarte, Roberto Alvim e o atual Secretário Mário Frias.

Essa guerra cultural que estamos enfrentando, orquestrada nas tomadas de decisão, nomeações, cortes, extinção da pasta da Cultura, por parte do governo, que nomeia de combate ao marxismo cultural, desconsidera, omite, as reais contradições de um capitalismo que leva ao esfacelamento do Estado, das políticas públicas, dos direitos básicos garantidos na Constituição em nome do livre mercado. De que direitos humanos se fala, de que democracia, se estão atingindo direitos básicos que estão na constituição? Com uma guerra de classes, como apontava Marx, o desmonte nos campos federal, estadual, municipal, o acirramento das desigualdades, a crescente recessão, a precarização do mercado de trabalho, com a chamada uberização. E o crescimento da pobreza das populações nas favelas, sem-teto, sem-terra, pessoas em situação de rua, indígenas, quilombolas, trabalhadores do campo, terceirizados, entregadores de aplicativo, artistas de rua, slams, artesanato. Sobretudo, na área da Cultura, cujos profissionais atuam, em sua maioria, de maneira informal, autônoma (RODRIGUES; PARDO, 2020, p. 242).

Ao pontuar as principais perdas para os trabalhadores e trabalhadores da Cultura, Stanley avalia que se trata de um desmonte do setor, assim como já haviam também considerado outros entrevistados como a Célia Maracajá. E destaca, de forma bem resumida, o que considera fundamental para melhorar as condições de trabalho.

Há um desmonte das estruturas do setor cultural, inclusive no setor audiovisual. 1) Interdição da Lei Federal de Incentivo à Cultura (Lei n 8.313/91 - Rouanet); 2) Paralisação do setor após a pandemia. A cultura voltar a ocupar um lugar de centralidade como vetor de desenvolvimento social e econômico (Ibidem, 2021).

\section{Algumas pesquisas e estudos sobre o setor cultural e os impactos da pandemia}




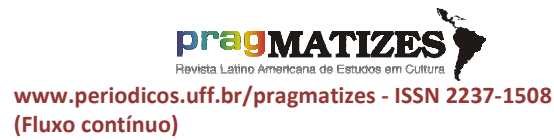
(Fluxo contínuo)
Para aprofundarmos ainda mais essa análise, feita com base nas questões trazidas pelos/as trabalhadores/as da Cultura, que se expressaram nessas entrevistas, apresentamos algumas pesquisas e estudos realizados sobre a crescente precarização do setor cultural, como também, os impactos gerados com a chegada da pandemia.

Para isso, acrescentamos a avaliação feita por Gustavo Portella Machado, que problematiza que as condições laborais da produção cultural têm positivado uma racionalidade neoliberal, normatizando a precarização do trabalho ao mesmo tempo em que responsabiliza os trabalhadores pelo sucesso individual e da economia geral. Ele considera que nesse modelo, o trabalhador da cultura passa a ser empresário e não funcionário, cuja função acaba sendo ser desvirtuada pelas empresas que o exploram. Precisa demonstrar criatividade, administrar conflitos, flexibilidade, paciência, trabalhar em equipe. Sem férias, $13^{\circ}$ salário, direitos trabalhistas e previdenciários. "Ao atuar sem contrato, com horários flexíveis, com forte pressão, com dificuldade de se pensar em longo prazo

(temporalmente

e

materialmente) e com alta dependência das redes sociais passa a apresentar um valor positivo, uma normalidade no campo laboral e da vida contemporânea" (MACHADO, 2019, p. 66). No entanto, essa dinâmica neoliberal carrega dimensões subjetivas, - como trabalhar sob pressão, atenção difusa, pró-atividade, etc, - que são incorporadas como précondições normativas e normalizadoras. Essas competências indicam que o trabalho de produtores artísticos e culturais carrega noções positivadas do empresariamento de si e da precarização do trabalho.

Em sua pesquisa, Machado considera que a formação de produtores culturais no mercado compreende a adequação de suas subjetividades às realidades mercantis que implicam a responsabilidade de si diante do sucesso seu e da economia geral. Mas também carrega os impactos de um possível fracasso, conforme ele cita o que Wendy Brown (2018) identifica nesse indivíduo responsabilizado, que isenta o Estado, a lei e a economia das condições precárias e das suas dificuldades. Por meio desse binômio 


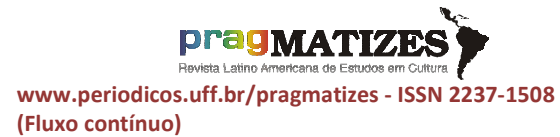

atuação/culpabilização, indivíduos são duplamente

responsabilizados: espera-se que cuidem de si mesmos (e são culpabilizados por seu próprio fracasso em prosperar) e do bem-estar econômico (e são culpabilizados pelo fracasso da economia em prosperar). Segundo ele, no mundo do trabalho cultural, a adoção do modelo por conta própria, que compreende o $\mathrm{MEI}$, já é a principal forma de ocupação, mesmo sem oferecer quaisquer benefícios e garantias formais de trabalho, esses trabalhadores são tratados como empresários.

De acordo com Lívia de Tommasi, os empreendedores seriam movidos por uma mistura entre senso de oportunidade e necessidade de sobrevivência. O peso distinto de cada um desses fatores depende, provavelmente, de onde os indivíduos estão colocados na escala social.

Os indivíduos contemporâneos são incitados a viver como se fossem projetos, a se tornar, cada um, empresário de si mesmo. No âmbito da racionalidade neoliberal, a autonomia do self é, ao mesmo tempo, objetivo e instrumento das estratégias de governo. A suposta autonomia dos trabalhadores "por conta própria" faz com que, além de assumir os riscos, eles tenham que assumir o ônus do fracasso em termos de responsabilização individual: se o negócio não deu certo, é porque ele não foi um "bom empreendedor", não tinha as qualidades e a ousadia necessárias. $O$ peso subjetivo do fracasso é significativo, em particular para os jovens. [...] A ideia central é que cada indivíduo tem a responsabilidade de se aproveitar das oportunidades que aparecem no caminho. Aos agentes externos, especificamente ao Estado, cabe simplesmente oferecer (de forma difusa) essas oportunidades. Assim, o direito ao trabalho é transformado em geração de oportunidade. Portanto, hoje não se trata de facilitar o acesso dos jovens ao primeiro emprego, e sim de oferecer oportunidades. O termo oportunidade é sinônimo de ocasião, possibilidade. [...] Acredito que as atuais transformações no mundo do trabalho devem ser compreendidas sem cair na tentação de ficar presos a representações binárias. É preciso escapar tanto dos entusiasmos simplistas sobre a presumida potência transformadora quanto do cinismo resignado que só vê cooptação, captura e derrota pelo neoliberalismo, o capital e o mercado (TOMMASI, 2016, p. 59$60)$.

$\mathrm{Na}$ avaliação do antropólogo e cientista social Néstor Garcla Canclini, a modernidade nos acostumou às novidades, primeiro com as vanguardas que se imaginava, como a superação da arte anterior e se 


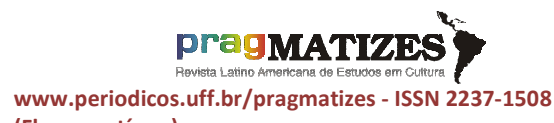
(Fluxo contínuo) substituíam umas às outras. Ele propõe uma outra interpretação acerca do cansaço da inovação vanguardista, "em parte pode-se ler como descrença em face da exigência da originalidade incessante e da visão progressista da história. Mas é também resultado da expropriação da criatividade social pelo capitalismo pós-fordista" (GARCÍA CANCLINI, 2016, p. 77). Ele também faz referência a Boltanski e Chiapello, ao analisarem quando os movimentos de contestação que sofreram um giro regressivo no momento em que a economia neoliberal se apropriou dessas demandas. Em que os manuais de gestão empresarial passam a promover a criatividade dos assalariados e premiam suas iniciativas inovadoras, o uso das tecnologias, especialmente nos setores de expansão, como os serviços e a produção cultural.

Assim, simula-se incorporar as fábricas à demanda cultural de verdade por meio de uma produção flexível em pequenas séries e da diversificação dos bens comerciais, sobretudo nos setores da moda, do design de objetos e dos serviços. Pretendese, desse modo, fazer com que o trabalho seja interessante, favorecendo à expressão pessoal e "ser um mesmo". Além de expropriar a inovação e incorporá-la à exploração do trabalho, intensificou-se a criatividade em design de produtos com 0 objetivo de atender às exigências e os gostos dos diferentes consumidores. Com isso, pretende-se desenvolver a liberdade de escolher. Como demonstrado por Boltanski e Chiapello (2002, p. 538), o que acontece realmente é um disciplinamento diversificado dos desejos, pois os fornecedores dos bens controlam o multiculturalismo dos gostos de seu repertório comercial de inovações. A oferta submete a demanda. (GARCÍA CANCLINI 2016, p. 78).

De acordo com os recentes dados, o setor cultural ocupava, em 2018, mais de 5 milhões de pessoas, de acordo com dados da Pesquisa Nacional por Amostra de Domicílios Contínua (PNAD Contínua), representando $5,7 \%$ do total de ocupados no país. Mais da metade eram mulheres $(50,5 \%)$, pessoas de cor ou raça branca $(52,6 \%)$ e com menos de 40 anos de idade (54,9\%).

Além disso, se comparado ao total das ocupações, o percentual daqueles com nível superior era maior (26,9\% no setor cultural ante $19,9 \%$ no total de ocupados). A partir dessa pesquisa, é possível perceber o aumento da informalidade no setor 


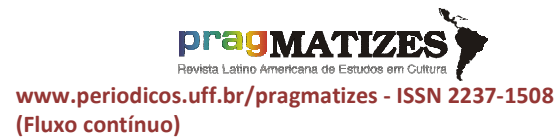
(Fluxo contínuo) cultural, no período analisado de 2014 a 2018. Entre os trabalhadores na cultura, essa tendência de redução do trabalhador do setor privado com carteira assinada e o aumento de trabalhadores por conta própria ocorreu em todas as grandes regiões. Contudo, apenas na região Sul, em 2018, o empregado da cultura e com carteira apresentava uma participação maior de pessoas $(43,3 \%)$ do que o por conta própria $(37,5 \%)$. A região Nordeste tinha o maior percentual de empregados do setor privado sem carteira $(16,7 \%)$ e de trabalhadores por conta própria $(47,5 \%)^{4}$.

Segundo estimativa da Fundação Getúlio Vargas (FGV), 2020 no "Atlas Econômico da Cultura Brasileira", o impacto social e econômico da pandemia - em curto e longo prazo - no setor cultural brasileiro é brutal. Conforme os dados da Pesquisa Nacional por Amostra de Domicílio (PNAD), de 2018, o setor representa em torno de $5,7 \%$, ou seja,

\footnotetext{
${ }^{4}$ Agência de Notícias IBGE, Editoria: Estatísticas Sociais, 05/12/2019. Disponível em:

https://agenciadenoticias.ibge.gov.br/agenciasala-de-imprensa/2013-agencia-denoticias/releases/26235-siic-2007-2018-setorcultural-ocupa-5-2-milhoes-de-pessoas-em2018-tendo-movimentado-r-226-bilhoes-noano-anterior .
}

mais de 5 milhões de trabalhadoras e trabalhadores no país, sendo que $44 \%$ destes profissionais são autônomos. A economia da cultura, que representa $5,4 \%$ do Produto Interno Bruto - PIB mundial, gera cerca de 180 milhões de postos de trabalho em todo o planeta. A participação feminina nesta força de trabalho é da ordem de 57,2\%. A situação ainda é mais grave devido ao fato de que os vínculos trabalhistas no setor cultural são majoritariamente precários, informais e temporários. As consequências deste impacto serão longas e difíceis no Brasil e em todo o mundo.

Nesse profundo impacto, o setor da Cultura, - que já atua em áreas rurais e urbanas, na informalidade, de maneira autônoma e bastante precária, sem nenhuma garantia de renda, e cujo ofício exige a presença humana, a interação e o contato físico, - foi um dos primeiros a serem diretamente atingidos, ao ser obrigado a interromper as suas atividades. Com o fechamento de cinemas, teatros, espaços culturais, lançamentos adiados, espetáculos cancelados, sem nenhuma previsão de retorno. E um número incontável de artistas e demais 


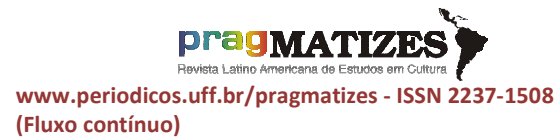
(Fluxo contínuo) profissionais da Cultura, que estão desempregados e bastante precarizados diante das dificuldades de manterem as condições básicas de sobrevivência e sem renda para a manutenção dos espaços. A Organização Internacional do Trabalho (OIT), em informe intitulado "COVID-19 e o mundo do trabalho", avalia que esta crise têm consequências devastadoras, e que a paralisação parcial ou total de setores da economia afetam 2,7 bilhões de trabalhadores, ou $81 \%$ da força de trabalho mundial.

Entre os setores mais afetados, a situação laboral de trabalhadores das áreas de arte, cultura $\mathrm{e}$ entretenimento é avaliada pela OIT como de "alto risco".

Com lançamentos adiados, espetáculos cancelados e um número incontável de artistas e demais profissionais da Cultura sem nenhuma renda. Ainda sem estimativas precisas do impacto econômico da crise causada pelo coronavírus (Covid-19) para o setor cultural no Brasil, é possível avaliar que as consequências são sem precedentes e podem perdurar por longo tempo, mesmo depois de contido o vírus, uma vez que a economia como um todo já está sofrendo as consequências.

No Rio de Janeiro, existem em torno de 21 mil Microempreendedores Individuais (MEls), que atuam e sobrevivem exclusivamente do trabalho realizado junto às Artes e à Cultura. Somente na cidade do Rio, capital do Estado Fluminense, são cerca de 93 salas de teatro e mais 370 cinemas, além de espaços culturais alternativos que estão fechados. São atividades presenciais de artistas de rua, de teatro, circo, dança, folias, cordéis, cirandas, slams, poesias, grafites, pinturas corporais, artesanatos indígenas e quilombolas e apresentações de música nos bares, restaurantes e nas ruas, agora paralisadas pela pandemia. E somente uma parcela reduzida tem de fato condições e qualquer apoio para fazer e transmitir arte pelas redes sociais.

A cidade e o estado do Rio têm uma trajetória de ocupação e emprego bastante dramática, sobretudo no período entre 2015 e 2020. De acordo com os dados do Ministério da Economia, no período de janeiro de 2015 a dezembro de 2020, o estado do Rio de Janeiro perdeu 702.148 empregos com carteira assinada. 


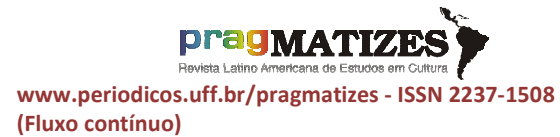
(Fluxo contínuo)

nacionais e internacionais, que atuam no Brasil, principal centro financeiro e cultural, acompanha o dinamismo brasileiro. Porém, a partir da transferência da capital para Brasília, a cidade e o estado do Rio passam a ser lanterna em termos de dinamismo econômico.

empregos. E a cidade do Rio perdeu mais empregos que a cidade de São Paulo, apesar da economia de São Paulo ser mais que duas vezes maior que a economia da cidade do Rio. Embora essa crise estrutural do Rio de Janeiro seja bem mais antiga, mesmo sendo um centro financeiro e cultural do país, analisa o professor de Economia da UFRJ, Mauro Osório, conforme citado por Sidney Rezende ${ }^{5}$ :

O Rio que conhecemos nasce como porto e fortificação militar, como aponta Carlos Lessa no livro "Rio de Janeiro de todos os brasis". Posteriormente, vira a capital do Brasil. A partir da vinda da Família Real portuguesa para o Brasil, em 1808, o Rio se moderniza e, usando o conceito do historiador de arte Giulio Argan, vira o eixo da capitalidade brasileira, passando a ser a principal referência internacional do país. Entre 1930 e 1980, a economia brasileira, em média, dobra de tamanho a cada dez anos. Quem "puxa" esse dinamismo é São Paulo. No entanto, o Rio, como capital do país, sede de empresas

\footnotetext{
${ }^{5}$ REZENDE, Sidney, 14/02/2021, Jornal O Dia, pesquisado no site: https://odia.ig.com.br/colunas/sidneyrezende/2021/02/6084594-as-raizes-dadecadencia-do-estado-do-rio-de-janeiro.html
}

Com o cenário atual, o fenômeno deve se intensificar, conforme a pesquisa. Desde 2016, porém, o setor criativo já apresentava mais fechamentos de empresas do que a abertura destas. Com o cenário atual, o fenômeno deve se intensificar. "Certamente vamos assistir a eliminação de postos de trabalho e de empresas neste ano", complementa Valiati. Ele diz que '[...] podemos saber qual é o potencial de um setor específico e entender o que está sendo posto em risco" 6 .

Nessa matéria do Diário da Causa Operária, publicada no dia 4 de maio de 2020 , portanto no início da pandemia, já era possível prever os fortes impactos econômicos provocados no setor cultural, sendo possível perceber que não ficaria impune à crise capitalista e sanitária

\footnotetext{
${ }^{6}$ Diário da Causa Operária n 5998 , 04/05/2020, disponível em:

https://www.causaoperaria.org.br/quase-5milhoes-de-trabalhadores-da-cultura-saoatingidos/
} 


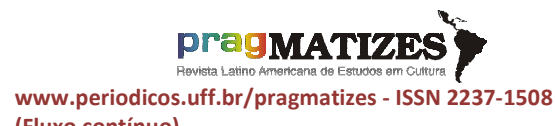
(Fluxo contínuo) que o país atravessa. Tendo em vista que em torno de cinco milhões de trabalhadores dependem deste importante meio de subsistência e já vinham sendo atingidos com 0 avanço do ataque aos direitos trabalhistas e a inviabilidade de apresentações artísticas por todo o Brasil devido à pandemia viral do Covid-19. Para Valiati, a cultura deverá sofrer ainda mais do que os demais setores, tendo em vista que nessa pandemia que a humanidade está enfrentando talvez provoque mudanças estruturais no perfil de consumo cultural, a exemplo da migração do show de música para o Spotify, do cinema para plataforma de streaming, que é uma tendência, e pode se intensificar. Esses impactos das tecnologias sobre as apresentações artísticas presenciais também foram abordados nas entrevistas. De outro lado, segundo a matéria do Diário da Causa Operária, não há uma política pública voltada para os profissionais da Cultura que ficaram sem renda, apontando para a necessidade de lutarem por seus direitos criando Conselhos Populares.
Enquanto isso há inúmeros artistas como os circenses e de rua que não podem trabalhar ou tiveram sua fonte de renda drasticamente reduzida porque dependem de público presencial. Não há sinal de qualquer política pública decente para estes profissionais que naturalmente já vivem uma realidade muito difícil com suas famílias. Os trabalhadores da economia criativa e de todo o setor cultural, abandonados à própria sorte, devem se unir e formar Conselhos Populares para lutarem pelo seu direito à sobrevivência ou serão massacrados pelos capitalistas que enxergam a arte apenas como status social e não como o ganha pão diário. Para tanto o Coletivo GARI (Grupo por uma Arte Revolucionária Independente) do PCO está à disposição de todos os companheiros que queiram somar-se a luta. (Idem).

Um estudo realizado pelo Painel de Dados do Itaú Cultural, lançado no dia 26 de novembro de 2020, revela que metade dos postos de trabalho ocupados por profissionais da Cultura deixou de existir entre junho de 2019 e 2020, resultando numa redução de $49 \%$.

De acordo com esse estudo, que tem como base a Pesquisa Nacional Por Amostra de Domicílios Contínua (PNAD Contínua), do Instituto Brasileiro de Geografia e Estatística - IBGE, no período analisado, o mercado editorial perdeu 


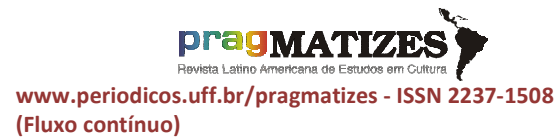
(Fluxo contínuo)
$76,85 \%$ de postos de trabalho, sendo 7.994 empregos a menos, as atividades artesanais também ficaram prejudicadas, com um prejuízo de $49,66 \%$, resultando na diminuição de 132,8 mil postos de trabalho. As perdas nas artes visuais e nas artes cênicas são de 43\% (97.823), enquanto o cinema, fotografia, música, rádio e tv perderam $38,71 \%(43.845)^{7}$.

Cerca de 900 mil dos trabalhadores da cultura no Brasil, formais e informais, perderam seus empregos entre dezembro de 2019 e junho de 2020. Esse grupo inclui atividades artesanais, cinema, teatro, rádio, $\mathrm{TV}$, fotografia, artes visuais $\mathrm{e}$ setor editorial. $\mathrm{O}$ número total de pessoas empregadas no setor cultural era de 7 milhões em dezembro de 2019, mas caiu para 6 milhões e 200 mil em junho deste ano de 2020, uma queda de $12 \%$ de pessoas trabalhando na cultura. Os profissionais diretamente ligados às atividades culturais caíram de 659,9 mil para 333,7 mil - uma redução de $49 \%$. Essa queda, de quase $50 \%$, é

\footnotetext{
${ }^{7}$ Painel de Dados do Itaú Cultural, 2020, no site do Farol da Bahia:

https://www.faroldabahia.com/noticia/um-emcada-dois-profissionais-da-cultura-perdeutrabalho-em-2020
}

dramática, diz Eduardo Saron, diretor do Itaú Cultural, uma vez que mostra o impacto da pandemia nas linguagens artísticas, como cinema e teatro. "Mais do que nunca, vamos precisar de políticas públicas estruturantes para a cultura e setores criativos, assim que a pandemia passar" 8 .

Diante desse quadro dramático, agravado pelos impactos de uma crise sanitária e social causada pela pandemia do Covid-19, no Brasil, foi elaborado, em caráter de extrema urgência, o Projeto de Lei 1075, resultando na Lei de Emergência Cultural, de autoria da deputada Benedita da Silva (PT), Presidente da Comissão de Cultura na Câmara, e outros 23 deputados, de 8 partidos (PT, PSOL, PCdoB, Rede, PDT, PSB, $\mathrm{PL}$ e PSDB) e 14 estados, cuja relatora foi a deputada Jandira Feghali (PCdoB), que unificou em um só texto outros cinco projetos e teve como principal argumento a demonstração comprovada da fonte existente de origem dos 3 bilhões. Trata-se de uma verba já destinada para a Cultura e que estava paralisada no Fundo

\footnotetext{
${ }^{8}$ Nova Brasil FM Campinas, 27/11/2020, disponível em:

https://campinas.novabrasilfm.com.br/notasmusicais/12133
} 


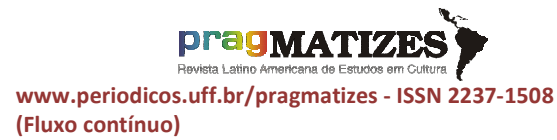
(Fluxo contínuo)
Nacional de Cultura (FNC) desde 2019.

Essa Lei (PL 1075/2020) foi aprovada na Câmara dos Deputados, no dia 26 de maio e no Senado no dia 4 de junho, sendo sancionada pela Presidência da República, em Brasília, no dia 29 de junho, como Lei de Emergência Cultural Aldir Blanc Lei 14.017/2020. Os 3 bilhões aprovados pela Lei Aldir Blanc foram distribuídos $50 \%$ para os municípios e $50 \%$ para os estados e o Distrito Federal, com o compromisso desses entes federados aplicarem em medidas emergenciais, em forma de repasse de uma renda básica, dividida em três parcelas, aos trabalhadores do setor cultural (tendo como base legal a Lei 13982/2020), subsídios para manutenção dos espaços culturais e artísticos independentes, microempresas e cooperativas; chamadas públicas, realização de cursos, produções, editais, meios de fomento e premiação simplificados, aquisição de bens e serviços do setor cultural.

No caso da cidade do Rio de Janeiro, que recebeu $R \$ 39$ milhões pela Lei Aldir Blanc, os dados informados no Cadastro, apresentado pela Secretaria Municipal de Cultura SMC-RJ e preenchido por mais de 6 mil agentes culturais, para a obtenção das medidas emergenciais da Lei Aldir Blanc, apontam que $92 \%$ não têm emprego formal e $94 \%$ paralisaram as atividades durante a pandemia. Foram, no total, mais de 14 mil cadastros realizados, sendo 6.196 de artistas individuais e 8.158 de espaços, grupos e coletivos. O mapeamento foi realizado via formulário online com o modelo de autoadesão e autodeclaração do agente cultural, que passou a compor o Mapa Cultural do Município do Rio de Janeiro. A iniciativa buscou atender à necessidade de construção do Mapeamento Cultural Carioca, em acordo com o Sistema Municipal de Cultura do Rio de Janeiro (Lei No 6.708 , de 15 de janeiro de 2020).

$\mathrm{O}$ alto índice de informalidade do mercado de trabalho brasileiro, - do total de 38,4 milhões de informais, 24,2 milhões são trabalhadores autônomos, o maior nível da série histórica iniciada em 2012, só é comparável, em anos recentes, aos piores momentos da crise econômica dos anos 1980. Hoje, o trabalho informal abrange $41,1 \%$ da população 


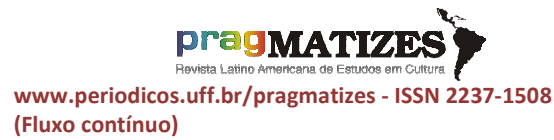
(Fluxo contínuo) economicamente ativa, o equivalente a 38,4 milhões de pessoas, segundo dados do IBGE. O percentual de trabalhadores autônomos que não possui CNPJ chega a quase $80 \%$. A informalidade inclui, ainda, as categorias de trabalhador sem carteira, trabalhadores domésticos sem carteira, empregador sem CNPJ e trabalhador familiar auxiliar. $\mathrm{O}$ crescimento da informalidade foi determinante para conter o aumento da taxa de desemprego nos últimos anos. De 2014 a 2019, a população desocupada quase dobrou, tendo crescido $87,7 \%$ e chegado a 12,6 milhões de brasileiros.

Especialistas ouvidos pela emissora internacional de jornalismo independente da Alemanha DW Brasil, atribuem o cenário atual a uma combinação de fatores, que passam pela escalada do desemprego que teve início a partir de 2015 e as decisões políticas posteriores que fragilizaram os vínculos no mundo do trabalho, como a reforma trabalhista e a lei da terceirização. As transformações, ocorridas no contexto da estagnação econômica iniciada há cinco anos, romperam uma trajetória de formalização que vinha sendo observada nos anos 2000. O professor de economia da USP, Ruy Braga, pontua que nessa década, $93 \%$ dos empregos criados eram formais. Entretanto, $63,7 \%$ dos postos de trabalho abertos no período estavam no setor de serviços, de remuneração mais baixa.

"A construção de um mercado regulado de trabalho, que articulava emprego e cidadania salarial, com direitos e uma forte presença do poder público protegendo 0 trabalhador, tomou décadas e esteve muito associado ao projeto de industrialização do país", afirma Ruy Braga $^{9}$. Segundo Braga, em 2018, a participação da indústria de transformação no Produto Interno Bruto (PIB) brasileiro atingiu o menor patamar desde o final dos anos 1940: $11,3 \%$. Nos anos 1980, a taxa chegou a se aproximar dos $30 \%$.

O horizonte de integração social via trabalho e direitos está se esfacelando. Temos uma parcela enorme da juventude exposta aos riscos desse modelo autoempreendedor popular sem uma formação profissional. Isso

\footnotetext{
${ }^{9}$ DW Brasil, 19/03/2020, em: https://www.dw.com/pt-br/epidemia-decoronav\%C3\%ADrus-exp\%C3\%B5evulnerabilidades-dauberiza\%C3\%A7\%C3\%A3o/a-52830974
} 


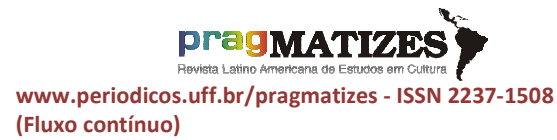
(Fluxo contínuo) pode construir um mercado bastante desregulado, e até selvagem, mas não constrói um país, segregando as pessoas do acesso a direitos básicos, como a aposentadoria (Ibidem).

\section{Caminhos incertos sobre o futuro do trabalho}

Iniciamos por considerar, a partir das condições precarizadas e sem quaisquer garantias de fontes de renda e o desmantelamento das políticas culturais no Brasil, que se expressaram nas vozes dos artistas entrevistados, apontam uma grande incerteza acerca do futuro do mercado de trabalho não somente na Cultura. Sobretudo, a partir de 2016, com a extinção da pasta do Ministério da Cultura e demais medidas tomadas por Michel Temer no governo, cujas perdas se intensificaram, desde 2019, nesse governo de Jair Bolsonaro, que decretou uma guerra cultural, além dos profundos impactos identificados no país e no mundo, a partir de 2020, causados pela pandemia do Covid-19.

De fato, vimos se esfacelar a cada dia o mercado regulado de trabalho e dos direitos, a perda de emprego e da cidadania, com muitas demissões, terceirizações, de autônomos, informais, a chamada uberização e as reformas trabalhistas e da previdência. Um sistema que concentra cada vez mais no indivíduo a responsabilidade de arcar com os riscos e incertezas para se autopromover, auto-empresariar e também se autoculpabilizar por suas perdas e fracassos, isentando 0 Estado, a lei e a economia pelas dificuldades e condições precárias enfrentadas num mercado extremamente concentrado, desigual, segregador e excludente. Quando consegue se destacar e alçar o cume é visibilizado como artista, mas é invisibilizado em seu labor enquanto assalariado comum, que tangencia a cada momento a sua condição de precariedade, ainda que muitas vezes obliterado pela falácia de ser "empreendedor".

Nesse cenário dramático, a exemplo de um mercado de trabalho e de um governo Bolsonaro que evidencia o mundo dos negócios, torna-se difícil garantir a retomada e a continuidade das políticas públicas voltadas para a Cultura que levem em conta a diversidade do país e a democratização do acesso a essas privatizações, um aumento significativo 


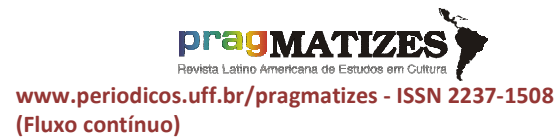
(Fluxo contínuo) políticas, sugerida pela maioria das/dos entrevistados.

Com base em suas falas e também nas análises feitas por diferentes pensadores, é possível perceber a necessidade de se repensar os significados dos termos cultura, trabalho, criatividade, empreendedorismo, como também, rever o papel do Estado. Além da função do empreendedor que passou a se desvirtuada e explorada pelas empresas, com o incremento de controle ideológico, de captura das subjetividades. Por outro lado, sabemos que não é todo mundo que consegue performar, empreender e cumprir o desempenho da chamada meritocracia, criando-se um exército de reserva para retroalimentar esse imaginário individualista. Se o trabalhador da cultura precisa assumir múltiplas tarefas e funções, de maneira independente, incerta, intermitente, sem nenhuma garantia de trabalho, renda e proteção social, ao invés de assumir o papel de empreendedor, que lhe designaram na intenção de fazê-lo sentir-se empresário, empoderado e reconhecido, cabe a ele, portanto, que carrega 0 sobrepeso laboral atravessado pela precariedade, utilizar a sua criatividade para se autonomear e mudar esse modelo de economia em nada criativa.

As políticas públicas culturais, que implicam em implementar ações que visam corrigir as distorções, de forma ampla, democrática e compartilhada com o acesso, a participação e o controle social da sociedade civil, não podem assumir um viés empresarial, empreendedorista, adotando o modelo e a defesa de interesses do mundo dos negócios, que concentra recursos públicos em grandes eventos e no entretenimento, conforme destacaram as/os entrevistados. Um modelo de cultura exploratória, espetacularizada, mercantilizada e oferecida como produto.

Nesse capitalismo estético, cultural, há uma estetização da crise com animação e entretenimento, diversão e clichês de publicidade, onde o empreendedor, embora contraditoriamente precário, é também levado a oferecer-se como produto vendável para atrair o mercado consumidor-espectador-cidadão. No sistema econômico de mercado, os objetos estão esvaziados de conteúdo, 


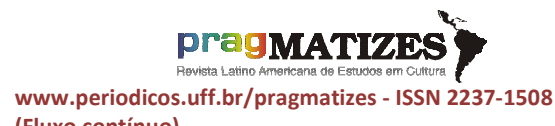
(Fluxo contínuo) o único valor existencial é o consumo, onde o irreal devora tudo e as pessoas viram paródias de si mesmas, autoras e vítimas de uma auto-encenação. $E$ uma expropriação de seres humanos e suas culturas, com o extermínio das populações indígenas, quilombolas e trabalhadores rurais, que vivem nas florestas enfrentam as constantes invasões, queimadas e conflitos com latifundiários, mineradoras, madeireiras na disputas pela terra. Em troca, é oferecido e estimulado um padrão fabricado com base no consumo, lucro e interesses do agronegócio e do mercado empresarial. Com a conivência e a liberação por parte do governo, como estamos vendo no momento atual. Após 520 anos, os corpos indígenas e sua existência seguem sendo resistência, para manter viva sua história.

É preciso escapar dessa lógica mercadológica, competitiva, excludente e concentrada em determinadas pessoas, áreas, regiões, projetos do chamado mérito cultural, que além de ser precária e autoexploratória, não é criativa, inclusiva e sequer cidadã.
Há muita potência inventiva e solidária em muitas comunidades cujos coletivos, territórios e equipamentos precisam ser reforçados, de forma permanente, a partir da ajuda mútua do trabalho comunitário para enfrentar conjuntamente 0 estado de precariedade cuja mudança passa fundamentalmente por uma nova Cultura.

\section{Referências bibliográficas:}

AGÊNCIA DE NOTÍCIAS IBGE, SIIC 2007-2018: Setor cultural ocupa 5,2 milhões de pessoas em 2018, tendo movimentado $\mathrm{R} \$ 226$ bilhões no ano anterior. Editoria: Estatísticas Sociais, 05/12/2019, Disponível em: https://agenciadenoticias.ibge.gov.br/a gencia-sala-de-imprensa/2013agencia-de-noticias/releases/26235siic-2007-2018-setor-cultural-ocupa-52-milhoes-de-pessoas-em-2018-tendomovimentado-r-226-bilhoes-no-anoanterior.

BOLTANSKI, Luc, CHIAPELLO, Ėve. O novo espírito do capitalismo. São Paulo: Martins Fontes, 2009.

BRASIL. Classificação Brasileira de Ocupações - CBO. 3 ed. Brasília. TEM. SPPE, 2010.

BROWN, Wendy. Cidadania sacrificial, neoliberalismo, capital humano e políticas de austeridade. Rio de Janeiro: Zazie Edições, 2018.

DIÁRIO DA CAUSA OPERÁRIA $\mathrm{n}^{\circ}$ 5998, Abandonados à própria sorte - 


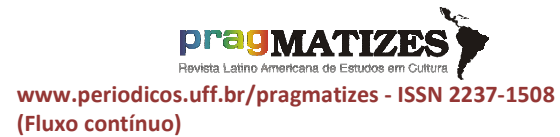
(Fluxo contínuo)
Quase 5 milhões de trabalhadores da Cultura são atingidos, 04/05/2020, disponível no site: https://www.causaoperaria.org.br/quas e-5-milhoes-de-trabalhadores-dacultura-sao-atingidos/

DW BRASIL, 19/03/2020. Disponível em: $\quad$ https://www.dw.com/ptbr/epidemia-de-coronav\%C3\%ADrusexp\%C3\%B5e-vulnerabilidades-dauberiza\%C3\%A7\%C3\%A3o/a52830974

FRANÇA, Wildson de Andrade. Entrevista concedida à autora, Rio de Janeiro, 25/01/2021.

MACHADO, Gustavo Portella Microempreendedor individual e desproteção social: tensões entre a racionalidade neoliberal e as estratégias para "viver de cultura" a partir de produtores/as culturais freelancers na cidade do Rio de Janeiro. Ponto-e-vírgula, PUC-SP, número 27, p 99-113, primeiro semestre 2020.

MACHADO, Gustavo Portella. O ensino da produção cultural entre o mercado e a Universidade: um estudo de caso a partir da trajetória na graduação em produção cultural da Universidade Federal Fluminense, Rev. Ed. Popular, Uberlândia, Ed. Especial, p. 59-72, 2019.

MADEIRA, Daphne. Entrevista concedida à autora, Rio de Janeiro, 15/01/2021.

MARACAJÁ, Célia. Entrevista concedida à autora, Rio de Janeiro, 05/01/2021.

MELO JÚNIOR, Gabriel Bezerra de. Entrevista concedida à autora, Rio de Janeiro, 15/02/2021.
MILFOND, Denise. Entrevista concedida à autora, Rio de Janeiro, 10/02/2021.

MIRANDA, José Carlos Rosa. Entrevista concedida à autora, Rio de Janeiro, 22/01/2021.

MORAIS, Ynaê Cortez de. Entrevista concedida à autora, Rio de Janeiro, 27/01/2021.

NOVA BRASIL FM Campinas, Um em cada dois profissionais especializados da Cultura perdeu trabalho em 2020, 27/11/2020. Disponível em: https://campinas.novabrasilfm.com.br/n otas-musicais/12133)

PAINEL DE DADOS do Itaú Cultural, $2020 . \quad$ Disponível em: https://www.faroldabahia.com/noticia/u m-em-cada-dois-profissionais-dacultura-perdeu-trabalho-em-2020

RAMOS, Mauro. PEC do Teto dos Gastos inviabilizou a educação pública no país, diz Dermeval Saviani. Brasil de Fato, Política, São Paulo, 08 de Dezembro de 2017. Disponível em: https://www.brasildefato.com.br/2017/1 2/08/pec-do-teto-dos-gastosinviabilizou-a-educacao-pubica-nobrasil-diz-dermeval-saviani

REZENDE, Sidney. As raízes da decadência do estado do Rio de Janeiro, Jornal O Dia, 14/02/2021. Disponível em: https://odia.ig.com.br/colunas/sidneyrezende/2021/02/6084594-as-raizesda-decadencia-do-estado-do-rio-dejaneiro.html.

RODRIGUES, Luiz Augusto; PARDO, Ana Lúcia. Desmanche e retrocesso das políticas públicas federais de cultura no Brasil. La Roca, Argentina, Ano 7, Número 7, p. 214-245, 2020. 
SANTANA, Erisvelton de Alencar. Entrevista concedida à autora, Rio de Janeiro, 20/01/2021.

TOMMASI, Lívia De. Jovens produtores culturais de favela. Linhas Críticas, Brasília (UnB), v.22, n.47, p. 41-62, jan./abr., 2016. Disponível em: https://periodicos.unb.br/index.php/linh ascriticas/article/view/4766

$\mathrm{VICH}$, Victor, $\mathrm{O}$ que é um gestor cultural? In: CALABRE, Lia; LIMA, Deborah Rebello (orgs.), Políticas culturais: conjunturas e territorialidades. Rio de Janeiro: Fundação Casa de Rui Barbosa ; São Paulo: Itaú Cultural, 2017. p. 49-54.

WHIBBE, Stanley Livingstone. Entrevista concedida à autora, Rio de Janeiro, 18/01/2021.

YIN, Robert K. Estudo de Caso Planejamento e. Método, Editora Bookman, Porto Alegre, 2003. 